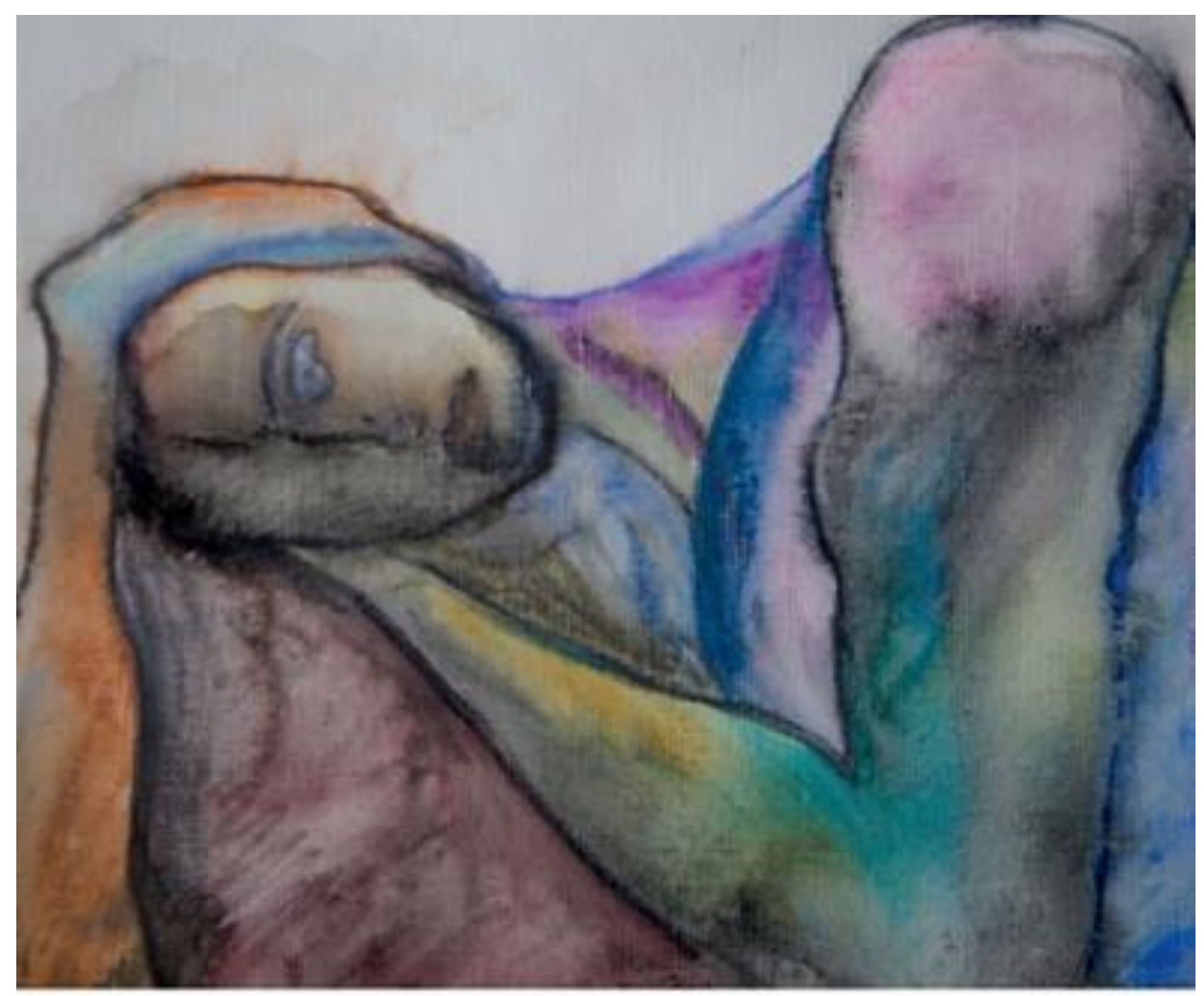

\title{
Transitional Justice and Forced Migration
}

Critical Perspectives from the

Global South

\section{Edited by Nergis Canefe}




\title{
Transitional Justice and Forced Migration
}

\author{
CRITICAL PERSPECTIVES FROM THE GLOBAL \\ SOUTH
}

\author{
Edited by
}

NERGIS CANEFE

York University, Toronto 


\title{
Beyond Agreements
}

\section{Management Tools to Support Peace Agreements in the Case of Displaced Populations in Colombia}

\author{
Fabio Andrés Díaz Pabón
}

\section{INTRODUCTION}

In this chapter, I demonstrate that simulation models, and in particular system dynamics models, could be a cheap and efficient way of examining policies that could allow public servants and service providers to learn and evaluate the different scenarios they are facing in delivering transitional justice remedies. ${ }^{1}$ In particular, I concentrate on the simulation ${ }^{2}$ and resultant evaluation of possible alternatives to be considered in relation to the reparation and restitution of land rights for the victims of forced displacement in Colombia. To this end, this chapter first presents a brief description of the phenomenon of forced displacement in Colombia and its impact on the society as a whole, thus highlighting the nature of the challenge for government institutions in tackling the results of decades-long conflict in the country. Then the chapter links these issues with the necessity of using managerial tools (in this case, simulation models) to assess scenarios and policies in relation to public policy initiatives and the overall transitional justice mandate. The chapter presents the reparation and restitution of lands in accordance to Law $144^{8}$ and the case of victims of forced displacement as a test case. It also discusses the limitation of the use of simulation models and the need to avoid an empiricist fever in their use. The methodological lens used here makes an important contribution to the overall debate on

This chapter is based on a paper written with Felipe Venegas titled: "Managing Peacebuilding: The Use of Managerial Tools to Support Policymaking after a Peace Process" for the International Association for the Study of Forced Migration 2014 conference in Bogotd, Colombia.

' C. Olaya, "Cows, Agency, and the Significance of Operational Thinking," System Dynamics Review, 31, no. 4 (2015): $183-219$.

2 The simulation was conducted to evaluate the impact on the system of different scenarios using simulation models for the "virtual" modeling of different alternatives. 
the transitional justice and forced migration nexus, in terms of keeping the focus strictly on national actors and domestic remedies as opposed to reliance on donor structures, international responses, and formulaic solutions.

The "Colombian armed conflict" is a term used to describe a complex conflict that has involved several actors since the mid-1g6os. The exertion of violence against civilians caught in the crossfire during the confrontation between irregular armed forces (FARC-EP, Ejército de Liberación Nacional (ELN), paramilitaries, etc. $)^{3}$ and government forces has been a regular facet of this conflict. ${ }^{4}$ Locally, the population that has been a victim to forced and violent displacement from their homes in the crossfire of the conflict is generically referred to as "the displaced" [desplazados por la violencia]. According to the United Nations High Commissioner for Refugees (UNHCR), this drama has produced more than five million victims. ${ }^{5}$ According to the Colombian government, the number of internally displaced Colombians amounts to more than seven million citizens. In consideration of other human rights abuses, the number of victims in Colombia increases to a staggering 8.376 million. ${ }^{6}$

Since 2012 a beacon of hope emerged for the victims of the conflict, as a peace process began between the biggest armed group in Colombia (FARCEP) and the Colombian government. The negotiations were finalized with the peace agreements signed in November 2016.7 The negotiation process was accompanied by a series of additional gestures by the government in power, which, for the first time, recognized the casualties caused by government forces as victims and recognized the Colombian violence as an internal armed conflict. Concomitantly, the government established a series of legal measures that recognized victims and their rights, and set up new institutions that could support the peace negotiations. This process, built on jurisdiction and jurisprudence related to previous peace processes, paved the way for the idea that conditions for justice might be ripe for victims of the armed conflict. ${ }^{8}$

3 The Revolutionary Armed Forces of Colombia - People's Army (Spanish: Fuerzas Armadas Revolucionarias de Colombia - Ejército del Pueblo, FARC-EP and FARC).

4 Cour Pénale Internationale, "Report on Preliminary Examination Activities 2013," Office of the Prosecutor, 2013.

5 See Office of the United Nations High Commissioner for Refugees, accessed July 20, 2018, www.unhcr.org/cgi-bin/texis/vtx/page?page=49e49zad6

6 Unidad para la Atención y Reparación Integral a las Víctimas, "Víctimas por tipo de hecho victimizante," 2017, http://mi.unidadvictimas.gov.co/RUV

7 Gobierno de Colombia and FARC-EP, “Acuerdo final para la teminación del conflicto y la construcción de una paz estable y duradera," 2016, www.altocomisionadoparalapaz.gov.co/pr ocesos-y-conversaciones/Documentos\%zocompartidos/24-11-2016NuevoAcuerdoFinal.pdf

8 C. López, "Aprender de nuestra experiencia para que la paz sí le cumpla esta vez a los colombianos," Revista de Ingeniería 44 (2016): 14-19. 
However, two interventions need to be made here. First, although a peace agreement has been signed with the FARC-EP, other armed groups have not signed peace agreements as yet, such as the ELN, ${ }^{9}$ the Ejército Popular de Liberación (EPL), ${ }^{10}$ and the Autodefensas Gaitanistas de Colombia (AGC). ${ }^{11}$ Secondly, peace is a broader concept that goes beyond negotiations with the FARC-EP. Thus, although the agreements with the FARC have reduced violence, they will not bring it to a halt. Proof of this is the targeting of human rights activists and similar attacks by other groups that are still active and exerting violence in the country. ${ }^{12}$ This adds complexity to the government's efforts to provide justice to the victims of the conflict. Furthermore, other armed groups are still capable of interfering with the processes of justice, reparation, restitution, and restoration for victims. ${ }^{13}$ As a result, although victims have been granted rights, availability of legal mechanisms for the redress of the harms suffered do not alleviate the fact that their lives are still unfolding within a conflict setting. In other words Colombia is in a postagreement phase with the FARC-EP, not in a post-conflict phase.

The stakes concerning the implementation of the agreements are high. The success of the implementation of government policies toward peace could lead to the reassertion of a social covenant in Colombia, and failure could set negative precedents for future peace negotiations with remaining armed groups. ${ }^{14}$ As such, the challenge for Colombian institutions in the next decade is the implementation of the agreements signed in Bogotá, ${ }^{15}$ and proving the capacity of the state for achieving institutional capacity to fulfill the promises made in the agreements with the FARC-EP. This is a momentous task, especially since some politicians are openly hostile to the peace agreements

9 As of the time this chapter was written, the National Liberation Army is undertaking peace negotiations with the Colombian government.

v Ejército Popular de Liberación. Popular Liberation Army.

in Autodefensas Gaitanistas de Colombia, a paramilitary group that was a rebranding of the former AUC (Autodefensas Unidas de Colombia). The latter signed a peace agreement in 2006 with the Colombian government. However, it failed to demobilize its structures. For a detailed discussion on this, see (Pardo 2007).

12 Revista Semana, "Amnistía raja a Colombia en Derechos Humanos," 2017, www.semana.com/ nacion/articulo/amnistia-raja-a-colombia-en-derechos-humanos/516341

13 La Silla Vacía, "Van 27 alertas de la Defensoría y aún nadie detiene el avance de los paras en Chocó," 2017, http://lasillavacia.com/historia/van-27-alertas-de-la-defensoria-y-aun-nadiedetiene-el-avance-de-los-paras-en-choco-60570

44 M. Palacios, Entre la legitimidad y la violencia: Colombia 1875-1994 (Bogota: Editorial Norma, 2003).

15 Signed on November 24, 2016, the "Acuerdo final para la terminación del conflicto y la construcción de una paz estable y duradera” (Final agreement for the ending of the conflict and the building of a sable and lasting peace). 
and promoting their revocation. ${ }^{16}$ This is also the context in which the country started a reparation process for the victims of the armed conflict who were forcibly displaced from their land during the last two decades. In particular, Law $1448^{17}$ established a series of ambitious goals that set measures toward the reparation of the victims of the conflict. Law 1448 defined the principles for reparation, restitution of land, compensation schemes, and the warranties of nonrepetition of violent acts that victimized more than 14 percent of the Colombian population. ${ }^{18}$ Furthermore, this initiative by the government was implemented before the agreement with the FARC-EP was completed, and thus constitutes the first formal step toward achieving transitional justice in the country.

However, in a context where there is weak institutional capacity, difficulties for small municipalities and territories to design and execute public policies constitute particular challenges for the implementation of the law. ${ }^{19}$ This is also evident with regard to the implementation of agreements between the government and the FARC-EP. On the one hand, normative frameworks provide guidelines for when and how victims should be served justice, and the deadlines for completion. On the other hand, guidelines on how to achieve these goals, especially given the magnitude of the task at hand, are absent. ${ }^{20}$ To make matters even more complicated, the number of victims of forced displacement keeps increasing, since violence has not fully stopped. As mentioned earlier, other groups who are not yet part of the peace process still exert violence upon civilians. Therefore, in the best-case scenario, any action undertaken by the government would be able to deal with past challenges, but would not be able to foresee where or when new problems might appear.

In this unstable environment, public officers are facing the almostimpossible task of restituting victims of forced displacement. ${ }^{21}$ For instance, in spite of the conditions and time frames set by the law, government

${ }^{16}$ New York Times Editorial Board, "The Man Blocking Peace in Colombia," The New York Times, October 14, 2016, www.nytimes.com/2016/10/14/opinion/the-man-blocking-peace-in-c olombia.html?_r=0

17 Congreso de la Republica de Colombia, "Ley $144^{8}$ de 2011," 2011, www.unidadvictimas.gov.co/ es/ley-1448-de-2011/13653

18 O. Huertas Díaz, "Restitución de Tierras, en el Marco del Conflicto Armado en Colombia: Propuesta legislativa de reparación para las víctimas," Verba Juris (2012): 3-45.

19 J. Vargas Reina, "Análisis comparativo de los diseños institucionales que regulan la participación de las víctimas en Colombia: antes y después de la Ley $144^{8}$ de 2012," Estudios SocioJurídicos (2014): 175 .

2o A.M. Mendoza Pineros and J.I. Gonzales Borrero, El desplazamiento forzado en Colombia y la intervención del estado: una mirada desde el goce efectivo de derechos y los factores asociados a su realización (Bogotá: Documentos CEDE, 2010), 2.

21 Ibid., 3 . 
institutions in charge of restituting land rights seem to be underperforming, ${ }^{22}$ with victims having to wait longer than the time frame that was set by law and, in some cases, facing worrying forecasts concerning the institutional capacity of the state to achieve the overall mandate of the law. ${ }^{23}$ These problems are in part the consequence of a mismatch between theory and practice, between norms and procedures. This is particularly salient in the case of reparations for the victims of forced displacement. It is expected that state institutions be steadfast and efficient in fulfilling a mandate written into law. However, lawyers, advocates, and legislators have fallen short of developing a framework for how to implement these measures. Although instructions look assertive and effective in the letter of the law and government mandates, they fail to provide illustrations and procedural guidelines for a bureaucracy saddled with a long-term internal conflict. In other words, legislation and norms are written as if Colombia was Olympus, a country where legal decisions are respected, incomes are high, inequality is nonexistent, the constitutional order is obeyed by citizens, so on and so forth. In effect', these laws have to be implemented in territories where warlords rule. There is an immense gap between what is expected (the law) and the reality on the ground. If transitional justice initiatives aim to help redress mass suffering, they need to start formulating how to bridge these gaps.

To understand these challenges, it is important to analyze the measures taken to redress the victims of forced displacement, ${ }^{24}$ so that laws and legislators are better equipped to deal with the organizational issues that emerge in fulfilling the mandate of transitional justice mechanisms. Debating the nature and reach of the law is necessary, as well, since discussing the problems of the reparation institutions is a healthy exercise that leads to improved accountability. In addition, it is imperative to propose how to improve the current system in order to ensure the level of service delivery that is expected by the affected public. In order to bridge the gap between what and how, I propose the use of simulation models ${ }^{25}$ as a tool to better understand the nature of the difficulties related to transitional justice policies. In turn, this would pave the way to diagnose and understand the true dimensions of the challenges, enable

22 Contraloría General de La República, "II Informe de seguimiento al proceso de restitución de tierras," Bogotá, 2013.

${ }^{23}$ F. Gutiérrez Sanín, Un trancón Fenomenal. Un analisis de las demoras en el proceso de restitución (Bogotá: Observatorio de restitución y regulación de derechos y de Propiedad Agraria, 2013).

24 Ibid.

25 A simulation model is a computer mock-up of a social model that can work as a prototype to understand its behavior in a virtual world. 
us to evaluate the effectiveness of existing institutions and procedures in place for reparation of the victims of displacement, and propose possible solutions to the failures of and weaknesses in the system.

\section{REDRESSING THE RIGHTS OF THE VICTIMS OF INTERNAL DISPLACEMENT IN COLOMBIA: LAW 1448}

The carnage and violence that engulfed Colombia for the past fifteen years must be understood first and foremost in the country's specific historical context. Violence has been systematically used in the country since the early twentieth century to displace people in order to gain control of their lands. ${ }^{26}$ In recent decades, however, these processes of possession via displacement have been accelerated and made worse by the presence of different armed actors, several guerrilla groups, private armies, drug lords, paramilitaries, and the government armed forces, leaving the civilian population in the crossfire of the possible combinations of confrontations among these actors (see Figure 5.1).

Indeed, understanding forced displacement in Colombia requires an assessment of the current situation as a by-product of the historical role played by violence and conflict in the illegal appropriation of assets in Colombia. These

\section{Million}

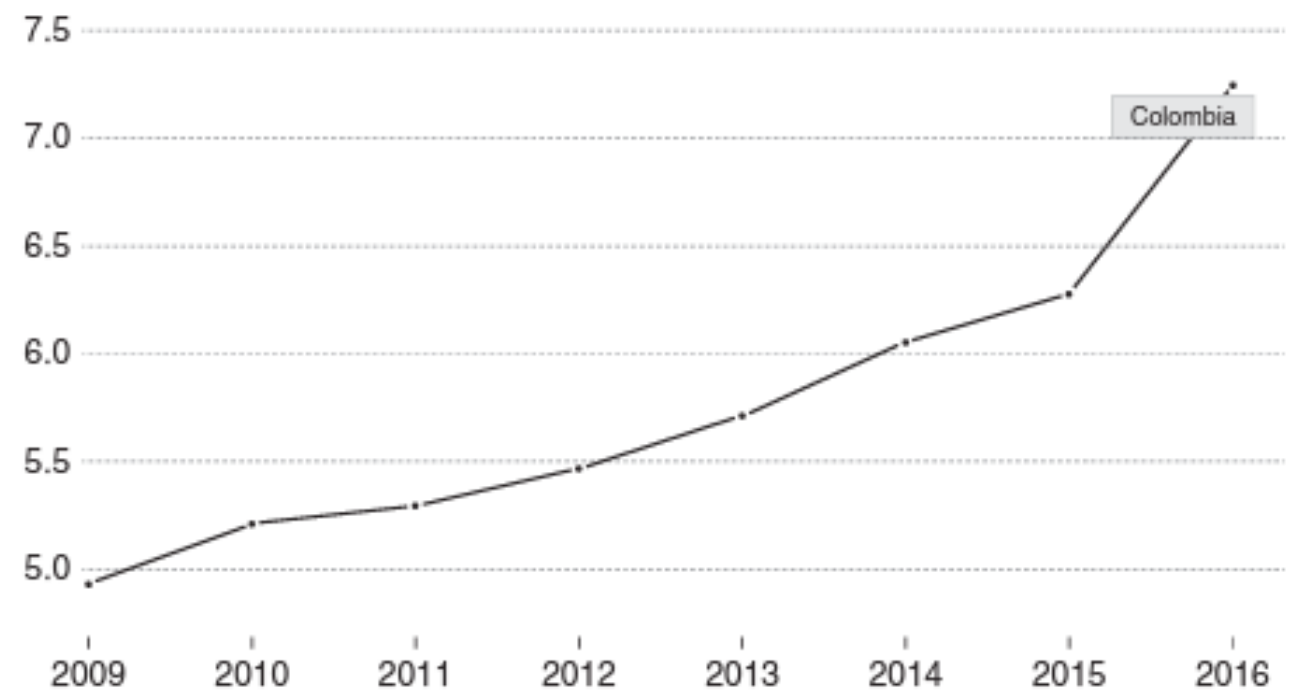

FIGURE 5.1 Colombia's internally displaced, estimates 2009-2016. Source World Bank. Retrieved from https://data.worldbank.org/indicator/VC.IDP.TOCV?locat ions $=\mathrm{CO} \&$ view $=$ chart on October 13, 2017 .

26 Palacios, Entre la legitimidad y la violencia. 
forms of appropriation have been resorted to by both the elites and the armed groups since the beginning of the twentieth century within a framework of a structurally unequal society. ${ }^{27}$ However, the current forms of violence have also been fostered by the presence of drug traffickers and large international corporations with investments in Colombian natural resources. ${ }^{28}$ One area that can be used to illuminate the extent and force of the role of violence in displacing Colombians from their homes is aggregate population figures. At the beginning of the 1940s, the demographical composition of Colombia was 25 percent urban and 75 percent rural population. These numbers changed dramatically via mass "urbanization" of the country, with a resultant composition of more than 75 percent urban, 25 percent rural population by the 1980 s. $^{29}$ This demographic shift is to be explained in part with reference to the use of violence that was resorted to by both conservative and liberal parties in different provinces of the country and during their struggle against each other in order to accumulate wealth and power. In effect, these confrontations pushed a segment of the population in the country to flee to urban areas in search of shelter from violence. In other words, urbanization was combined with escape from violence in the Colombian countryside. In this context, the statement of the Norwegian Refugee Council that the FARC-EP originated chiefly among the forcibly displaced people in extremely isolated areas of the country ${ }^{3 \circ}$ presents what may be called the Colombian paradox: the use of violence in Colombia created not just cycles of further violence but also new forms violence.

In terms of landmass, the area that has been abandoned because of forced displacement since 1998 accounts to a figure of around 5.5 million hectares. This is an area bigger than Switzerland, and is equal to 10.8 percent of arable agrarian land in the country. ${ }^{31}$ In 63 percent of cases, victims of the forced displacement were located in rural areas. ${ }^{32}$ Furthermore, displacement primarily targeted small landowners, as 28.6 percent of victims lost plots of less than 5 hectares, and more than $5^{1}$ percent of the plots taken away were between 5 and 15 hectares. ${ }^{33}$ Forced displacement seems to have had

\footnotetext{
27 Mendoza Pineros and Gonzales Borrero, El desplazamiento forzado, 7 .

28 Norwegian Refugee Council, “Colombia: Government 'Peace Process' Cements Injustice for IDPs," Internal Displacement Monitoring Centre, 2006, 9.

s9 Banco de la Republica de Colombia, "El campo y la ciudad: Colombia, de país rural a país urbano," 1999, www.banrepcultural.org/node/32860

3० Nonwegian Refugee Council, "Government 'Peace Process,"” 9.

${ }^{31}$ L.J. Garay, "Tragedia humanitaria del desplazamiento forzado en Colombia," Estudios Politicos (2009): 174 .

${ }^{32}$ Ibid., 156 .

33 Ibid., 175 .
} 
particularly vicious effects among Indigenous groups and Colombia's afrodescendants. Of the total figure of the forcibly displaced population, 23.6 percent of the displaced belong to an Indigenous group or to an afro-descendent group. ${ }^{34}$ These vicious attacks against the country's minorities can be illustrated by the 2012 figures on forced displacement in Colombia, as 44 percent of all victims of forced displacement in the country in that year were afrodescendants and Indigenous people. Whereas Indigenous groups and afrodescendants correspond to 14 percent of the total population of the country, they are three times more likely to be among the forcibly displaced than other groups and communities.

The consequences of internal displacement constitute a violation of the right to live, and to have a home and to reside in a particular place. Often, the scars of forced displacement placed affected citizens into a poverty trap that led to the displaced populations becoming further impoverished, dislocated, and alienated. Therefore, in spite of the fact that the relocation from rural areas to urban areas might imply a wider access to public services and protection, in reality it did not signify any significant benefit. ${ }^{35}$ Having access to some of the rights that should have been provided in their previous residence cannot be seen as a gain for people who have been forcibly displaced. The logic behind such an argument, whereby a potential increase in the enjoyment of basic rights is traded against the violation of another group of human rights, is a nonstarter.

In fact, the effects of displacement are nefarious. Poverty indexes of displaced households are higher than what they were in the places these groups inhabited before, since 99 percent of the victims of displacement currently live in poverty,,$^{36}$ and 77 percent of such households live in extreme poverty in their new settlements. ${ }^{37}$ This situation presents a stark contrast to their previous lives prior to their displacement, where poverty affected $5^{1}$ percent of the households that were displaced. This dramatic increase, leading to an almostdoubling of poverty, is explained by the changes in their income levels, whereby dislocation and violent expropriation of their assets hindered their economic capabilities. ${ }^{38}$ The decrease in their net income, which accounts to 9 percent in most cases, ${ }^{39}$ is magnified further by their insertion in places

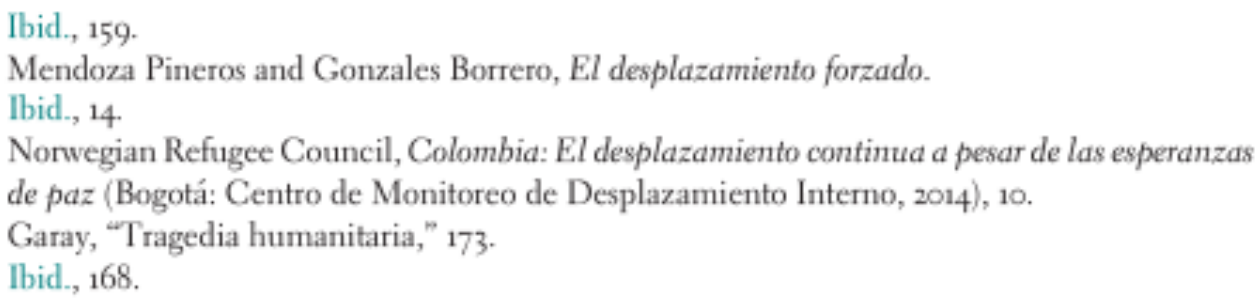


where the cost of living is higher. This, in addition to their social dislocation and the destruction of their support networks and social capital, leaves displaced people in a marked position of vulnerability. In a new city, being without assets, with low levels of education, and being stigmatized further limits their capacity to generate an income. Therein lie the value and importance of land restitution for the victims of displacement in the quest for peace. Landownership could allow displaced people to have better access to the tools with which to engage for the realization of their human rights in a more substantive way. Special policies crafted for the restitution, reparation, and generation of new assets are necessary to produce a real change in the socioeconomic condition of the displaced families. ${ }^{40}$ However, one also has to acknowledge that for some victims of forced displacement going back to a place where they were victimized is not a priority, in spite of the economic impoverishment they have suffered as a result of forced migration'. Their insertion into the economy of bigger cities may present better opportunities. ${ }^{41}$ In this regard, reparation and restitution do not consummate transitional justice measures addressing the rights of the displaced populations. Repairing the damage done by the actors of the conflict is needed to cement a new social covenant among Colombians. Overcoming the institutional and organizational challenges in relation to the reparation of the victims and the restitution of the land is just the beginning.

Indeed, the peace agreements reached between the FARC-EP and the Colombian government defined a series of mechanisms to address elements related to the structural causes that led to armed conflict in Colombia. The topics of political participation, state control of societal violence, rural reform, and the challenges posed by illicit crops and drugs present venues for change in policies that could lay the foundations of a new social covenant, and for the reassertion of the promises of the social contract defined by the 1991 Constitution..$^{42}$ In addition, current peace agreements present a series of mechanisms that would allow the establishment of a transitional justice framework in Colombia, incorporating initiatives such as a historical truth commission and a national human rights court. This would lead to the mixing of retributive and restorative justice methods, which is essential for addressing the plight of victims, who comprise 14 percent of the population, and offering them symbolic and effective redress.

4 Ibid.

4 Centro Nacional de memoria Histórica, "Una Nación Desplazada: Informe nacional del Desplazamiento forzado en Colombia," 2015, www.centrodememoriahistorica.gov.co/descar gas/informes2o15/nacion-desplazada/una-nacion-desplazada.pdf

4 Gobierno de Colombia \& FARC-EP, "Acuerdo final." 
An equally important point is that the current framework for transitional justice does not operate in a vacuum. In fact, the initiatives followed after the agreements with the FARC-EP were preceded by decades of similar efforts. The demobilization of ten different armed groups in the country has involved mechanisms, institutions, and practices to allow for the provision of justice and the reassertion of the sovereign capacity of the Colombian state. ${ }^{43}$ These previous peace agreements and initiatives highlight the trials and tribulations that marked the making of the modern state in Colombia. A key example of such past initiatives is Law $144^{8}$. Interestingly enough, this law did not emerge as part of a peace agreement. As already mentioned, it was informed by the peace process involving the paramilitary forces in 2006 , before the formal start of the peace negotiations with the FARC-EP. In 2011, the Colombian government signed the Victims and Land Restitution Law (Ley de Víctimas), intending to return stolen, confiscated, or abandoned land to forcibly displaced populations. ${ }^{44}$ This law prescribes that anyone who has been forcedly displaced from their lands/homes since January 1991 can request the Colombian state to either give their land back or financially compensate them in the event that land restitution is not possible. The law ordains that over a period of ten years (up until 2021), all of the cases should be resolved. To properly address all the claims, the Colombian government created the Land Restitution Unit (URT - Unidad de Restitución de Tierras), which is dedicated to analyzing every one of the requests from the possible victims and determining if the land is to be restituted. If the claim has validity, the URT has a mandate to offer reparations to the victims within the time frame defined by the law following a judicial process (see Figure 5.2).

Overall, the performance of the URT has been heavily criticized. ${ }^{45}$ By 2017, according to the latest report of the URT, less than 1 percent of the victims had been restituted. $4^{4}$ The causes for this can be linked to a series of elements endemic' to a complex problem such as the land scarcity issue in Colombia. In some cases, the areas where land has have been appropriated are still under the influence of armed groups, while in others the capacity of the government to

43 López, "Aprender de nuestra experiencia."

4 The law introduces a series of other elements for repairing other victims and other offenses committed during the Colombian conflict. However, they are outside of the scope of this chapter.

45 Contraloría General de La República, "Informe de seguimiento"; Procuraduría General de la Nación, "Persiste el incumplimiento en la implementación de la ley y los decretos leyes de víctimas y restitución de tierras," 2017, www.procuraduria.gov.co/portal/incumplimientorestitucion-victimas.news

$4^{6}$ See www.restituciondetierras.gov.co/estadisticas-de-restitucion-de-tierras, accessed zo July 2018. 


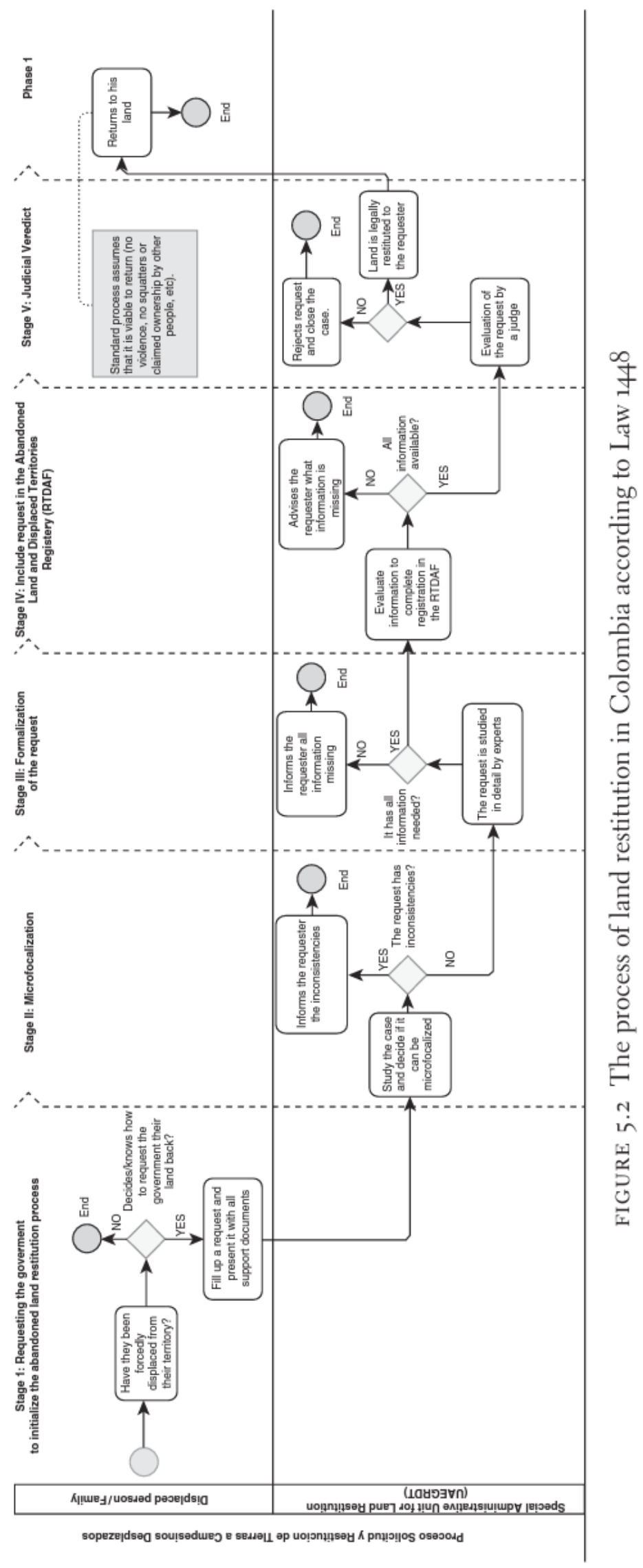


deal with the demand for restitution is not present. ${ }^{47}$ Finally, we must take into account that the process of restitution is mediated by a legal system, and this leads to a series of challenges posed by judicial processes. The entire process is bound by the necessity to coordinate different institutions, a situation which inevitably creates bottlenecks and delays. ${ }^{8}$ Indeed, the restitution process usually involves the coordination of the police forces, armed forces, the ombudsman's office, the general attorney's office, and other government institutions that can provide information about and support the claim.

Thus, the institutional capacity of the URT becomes vital, as the government tries to repair the damages suffered by the victims of the conflict. However, its institutional capacity at a decentralized level has been streched by tasks that are beyond its current administrative and managerial ability. ${ }^{49}$ This, in conjunction with the government's limited capacity to pursue policy initiatives with concrete actions at the local level, defines the limits of the overall possibility of repair for the victims..$^{50}$ As institutional capacity is a determinant factor in the realization of human rights,,$^{51}$ it is imperative to improve these deficiencies in the face of the challenges concerning the reparation of the victims..$^{52}$ It has been observed that although the law prescribes set periods of time for each stage of the reparation process, their implementation takes far more time than what was envisaged. ${ }^{53}$ For example, victims are meant to be informed about' their inclusion in the database of victims of conflict within a period of sixty days. However, for this stage alone of the process of reparation, delays can reach up to six months. ${ }^{54}$

The specific challenges concerning the restitution and reparation of victims of forced displacement can be summarized as follows: ${ }^{55}$

- Weak institutional capacity at the local level and lack of coordination between national and local initiatives;

- The implementation of the restitution and reparation processes in environments where violence and war have not ceased;

- In 94 percent of municipalities, scarce administrative and financial resources;

\footnotetext{
Gutiérrez Sanin, “Un trancón fenomenal.”

Contraloría General de La República, "Informe de seguimiento."

Mendoza Pineros and Gonzales Borrero, El desplazamiento forzado, 16.

Vargas Reina, "Análisis comparativo," 167.

Mendoza Pineros and Gonzales Borrero, El desplazamiento forzado, 34.

Norwegian Refugee Council, El desplazamiento continua.

Gutiérrez Sanin, "Un trancón fenomenal."

Norwegian Refugee Council, El desplazamiento continua, 12.

"Vargas Reina, "Análisis comparativo."
} 
- Lack of an integral legal project that deals with the land rights and lack of a proper land-based census in the country. ${ }^{56}$

Therefore, studying the implications of Law $144^{8}$ is very important for improving Colombian democracy, and in particular for developing public policy that would increase the legitimacy of the government and build on the recognition of the human rights of conflict victims. ${ }^{57}$ However, since the goal is to repair and restitute the rights of victims by 2021, this quest requires speed and efficiency from the policies and institutions designated to achieve this mandate. In this context, we must take the quest for human rights beyond the normative realm of what justice is into the practical realm of how to implement specific transitional justice initiatives.

\section{SIMULATION MODELS FOR PEACE-BUILDING: AN ANALYSIS \\ OF LAW 1448 IN COLOMBIA}

Simulation models can support the assessment of the challenges in planning and assessing the required resources for implementing a comprehensive policy toward the displaced population and victims of internally forced displacement in Colombia. However, the utility of these simulation tools cannot bypass the need to reflect on the goals that a transitional justice mechanism should aim for (the "what"). Computer models help us into operationalizing these goals in regards to the gaps faced in post-conflict scenarios (the "how"), but they are only useful in relation to a stated objective.

There are multiple tools and methodologies available for using, designing, and applying computer simulation for decision-making processes and public policy planning; in this case, I argue that the use of system dynamics methodology can be an effective approach that can support the assessment of the integrity and effectiveness of policies such as the ones designed by Law $144^{8.5^{8}}$ The utility of this approach resides in its capacity to allow policy-makers to analyze and explore the requirements, connections, and challenges involved in policies and institutions and their implementation, and thus to illustrate how delays, bottlenecks, and interconnections that are not evident can determine the success or failure of public policies. The greatest appeal of the use of computer modeling in this case is that it can take place in a virtual

\$7 Gutiérrez Sanin, "Un trancón fenomenal," 6.

$5^{8}$ Olaya, "Cows." 
environment before implementation. As such, system dynamics methodology can help policy-makers to learn from possible managerial mistakes without actually executing these actions and affecting the life of citizens (Sterman 1994). ${ }^{59}$ Thus, to understand the gaps between theory and practice, law (what) and (how) in regards to the Law $144^{8}$ should be assessed, reflecting on the barriers that affect compliance with the mandates of the law in practice. The following sections will explain the methodology employed and outline previous cases before we proceed to present the simulation model used for analyzing Law 1448. Simulation models are tools that can allow policymakers to see how the complex interactions of a particular problem unfold under different scenarios. ${ }^{6}$ Policy-makers can use simulation models to learn, test, and design different scenarios in relation to the case under study, and for learning about the operation and challenges of particular policies. ${ }^{61}$ The use of simulation models can also be a tool for policy-makers to train managers and staff in order to understand the complexities of programs and policies. ${ }^{62}$ Such use is particularly useful given that social systems are characterized by the presence of counterintuitive behaviors, where policies oftentimes present unexpected results, and delays between the implementation and the assessment of results make it difficult to understand the impacts of particular actions when there is no baseline study. ${ }^{63}$ The capacity of models to represent, map, and make explicit our understanding about how public policies work and what can affect their performance allows for reflection on aspects that might affect the performance of a policy or a program.

\section{CHALLENGES FACED DURING THE IMPLEMENTATION OF THE VICTIMS' LAW IN COLOMBIA}

Backlogs, delays, and the understanding of feedback processes are difficult to grasp unless they are mapped or made explicit. This kind of complexity (see Figure 5.3) is natural in situations where conditions are changing constantly, where policy decisions will affect the future state of the problem addressed by the policy being implemented, and where outcomes do not necessarily obey

J.D. Sterman, "Learning in and about Complex Systems," System Dynamics Review 2, no. 10 (1994): 291-330.

60 ISDPS, n.d.

6i N. Ghaffazedegan, J. Lyneis, and G.P. Richardson, "How Small System Dynamics Models Can Help the Public Policy Process," System Dynamics Review 27, no. 1 (2010): 22-44

62 J.D. Sterman, "System Dynamics Modelling: Tools for Learning in a Complex World," California Management Review 43, no. 4 (2001): 8-25.

${ }_{3}$ Ghaffazedegan et al., "Small System Dynamics Models." 
a linear structure. ${ }^{64}$ The case of the land restitution for victims of forced displacement is an example of such a complexity. For example, the modeling and understanding of the crisis of the victims of forced displacement must differentiate between the total number of people that have been displaced over a period of time, in comparison with the number of people displaced every year. This basic distinction presents different questions on how Law $144^{8}$ intends to deal with new victims of forced displacement. As the law envisioned it, the process would entail the restitution of victims of forced displacement between 1985 and 2011. However, the jurisdiction of the law also oversees the process for victims of forced displacement after 2011.

Another possibility for the use of a simulation model would be the analysis of the institutional capacity of the institutions put in place to attend the demand from victims for reparation. When the law defined the deadlines and processes of the restitution process (see Figure 5.2), the process was envisioned to' be impervious to changes regarding the number of claimants of restitution. The performance of the law would be defined by the capacity of the supply to respond to the demands from the citizens, and, to this extent, an analysis can be done using simulation models.

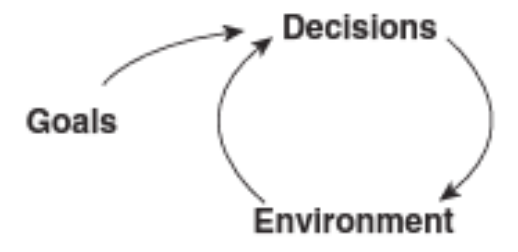

Our decisions alter our environment, leading to new decisions,

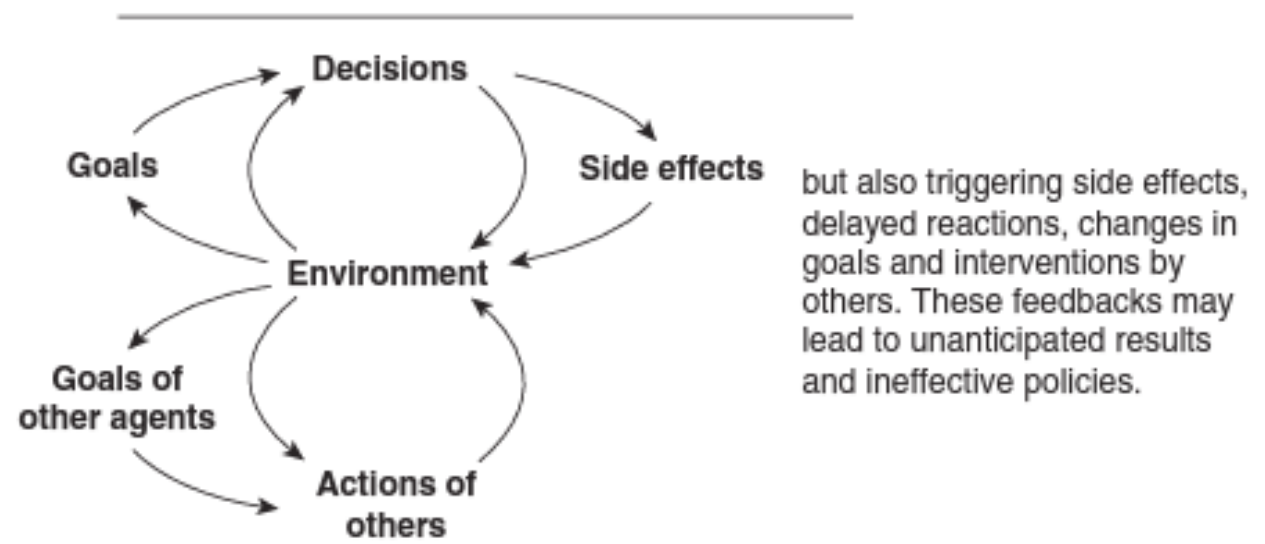

FIGURE 5.3 Complexities of social problems faced by policy-makers. Illustration of feedbacks and nonlinear effects. Source: Sterman, "System Dynamics Modelling," 14.

64 Sterman, "System Dynamics Modelling." 
Another aspect to consider is the effect of delays in the outcomes of the processes establishing the infrastructure for implementation of the law. Judges take time to be trained, and be instated in their positions; claims take time to be processed, and in a context of different institutions and several stages, small delays on these processes might imply dramatic changes in performance and the feasibility for the actual realization of the rights of the victims of forced displacement. Delays also make it more difficult for policy-makers to assess real progress, and the future progress of their policies. $^{65}$

Specifically, system dynamics is a methodology that has been used in policy analysis and design, which applies the idea of mapping the complexity and the interconnections between different actors, processes, and institutions to analyze and reflect on problems arising from the implementation of public policies. ${ }^{66}$ The approach is ideal for cases where interaction, interdependence, mutual interaction, information feedback, accumulation, delays, and circular causality exist. Meanwhile, it is important to highlight that system dynamics models do not provide predictions but they do provide policy tools to examine and learn about the behavior of key variables over time. Previous research on similar topics using this methodology has involved the study of the accumulation of cases that had to be evacuated and resolved by judges and government offices in order to assess further strategies and policies, and to examine the consequences of interactions of relevant variables. ${ }^{67}$ Particular models dealing with the phenomenon of displacement using system dynamics have been focused on the victims of forced displacement in Darfur and their allocation into concentration camps, analyzing the resettlement and return of the victims to their original homes, as well as' than presenting the flow of victims of displacement to the refugee camps. ${ }^{68}$

65 Ibid.

66 J.W. Forrester, "System Dynamics, Systems Thinking, and soft OR," System Dynamics Review 10, no. 2 (1994): 245-56.

67 C. Olaya, G. Diaz, and A.M. Ramos, The Power of the Stock: Accumulations in the Colombian Accusatory System Reform,"Proceedings of the 26 th International Conference of the System Dynamics Society, University of Patras, Athens, 2008; C. Olaya, "Model-Based Lawmaking and the Curious Case of the Colombian Criminal Justice System," Kybernetes 9, no. 39 (2010): 1678-1700.

68 J.B. Sato and B.J. Stansen, “A System Dynamics Approach to Analyzing Violence, Death and Displacement in Darfur," Conference Proceedings of the 2007 International Conference of the System Dynamics Society, Boston, July 29-August 2, 2007- 


\section{A SYSTEM DYNAMICS MODEL OF LAW $144^{8}$}

In order to assess a series of scenarios with regards to the process of land restitution dictated by Law $144^{8}$, we have built a simulation model encapsulating the process described in Figure 5.2. This model has four main sections. The first section (see Figure 5.4) represents the displaced population over time. A portion of the displaced population might decide to make a request to the government to be considered for the process of land restitution, whereas other segments of the victims of forced displacement will not present claims to this end. For this section of the model, we assume the capacity of the system to receive requests for land restitution is infinite and is not affected by the number of claims made. However, one should expect that the number of requests would affect the response rate by the institutions in charge of the process.

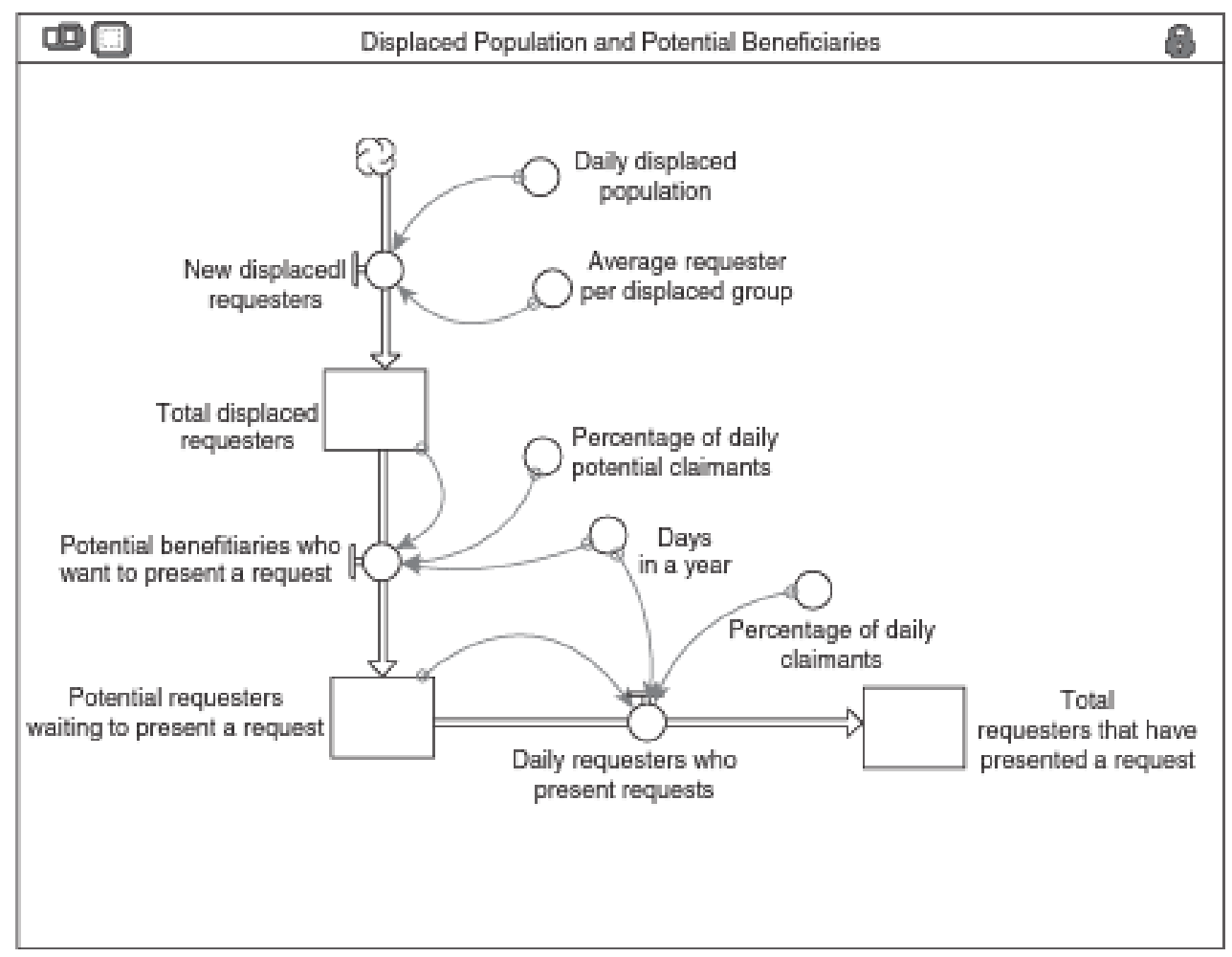

FIGURE 5.4 Displaced population and potential beneficiaries

The second section of the model (Figure 5.5) represents the different stages that the requests have to go through in the administrative process associated with the restitution. A request submitted by a potential beneficiary of the law is validated and revisited in all four steps of the process until the final stage, when 
a judge declares if the request has been accepted or denied. The first step is related to the "micro-focalization" ${ }^{\text {"69 }}$ of the case. In this context, there are two possibilities: either the land can be "micro-focalized" (a requirement of the law to initiate the process) or it cannot. If the requirement is fulfilled, the claim will move onto the next step, that is, the formalization of the requests. About 90 percent of the requests that enter the second step are formalized. The next step is the registration of the cases in the Registry of Forcibly Dispossessed and Abandoned Lands (RTDAF - Registro de Tierras Despojadas y Abandonadas Forzosamente), the national registry of lands forcibly dispossessed or abandoned due to violence. This process can take up to thirty days. The final step is the legal process that will produce a verdict on the case.

The last part of the model (Figure 5.6) presents the different steps the claim has to go through for the restitution of land, as a result of which a given parcel of land goes from a status of being abandoned to being restituted. This process is a parallel process to the legal and administrative process presented in Figure 5.4. It involves the effective material transfer of the claimed land. The model also estimates how many people would finally receive their land back.

\section{SIMULATION AS A TOOL FOR PEACE-BUILDING: AN ANALYSIS \\ OF THE IMPLEMENTATION OF THE LAND RESTITUTION PROCESS IN COLOMBIA (LAW 1448)}

The implementation of the peace agreements with the FARC-EP and the Colombia government in the form of transitional justice mechanisms implies a new set of challenges concerning the laws, procedures, and institutions related to the restoration of the rights of the victims of forced displacement. In other words, the signing of a peace agreement will not automatically lead to the elimination of the dramatic humanitarian crisis that the country has gone through. ${ }^{70}$ Still, the signing of the agreements in late November 2016 signifies a starting point for a new framework that is yet to unfold. As a tool of analysis, the models presented in this section will analyze two sets of conditions in order to assess the feasibility and the implications of restitution of the rights of the victims of displacement.

The first scenario will be an ideal-type scenario; as such, it will present the mandated time frame and processes as spelled out by the law. Thus, this scenario represents a simulation of the law as is, and its implementation

69 The process of micro-focalization refers to when a territory claimed can be validated and confirmed. This is an initial data validation step.

to Norwegian Refugee Council, El desplazamiento continud, 4. 


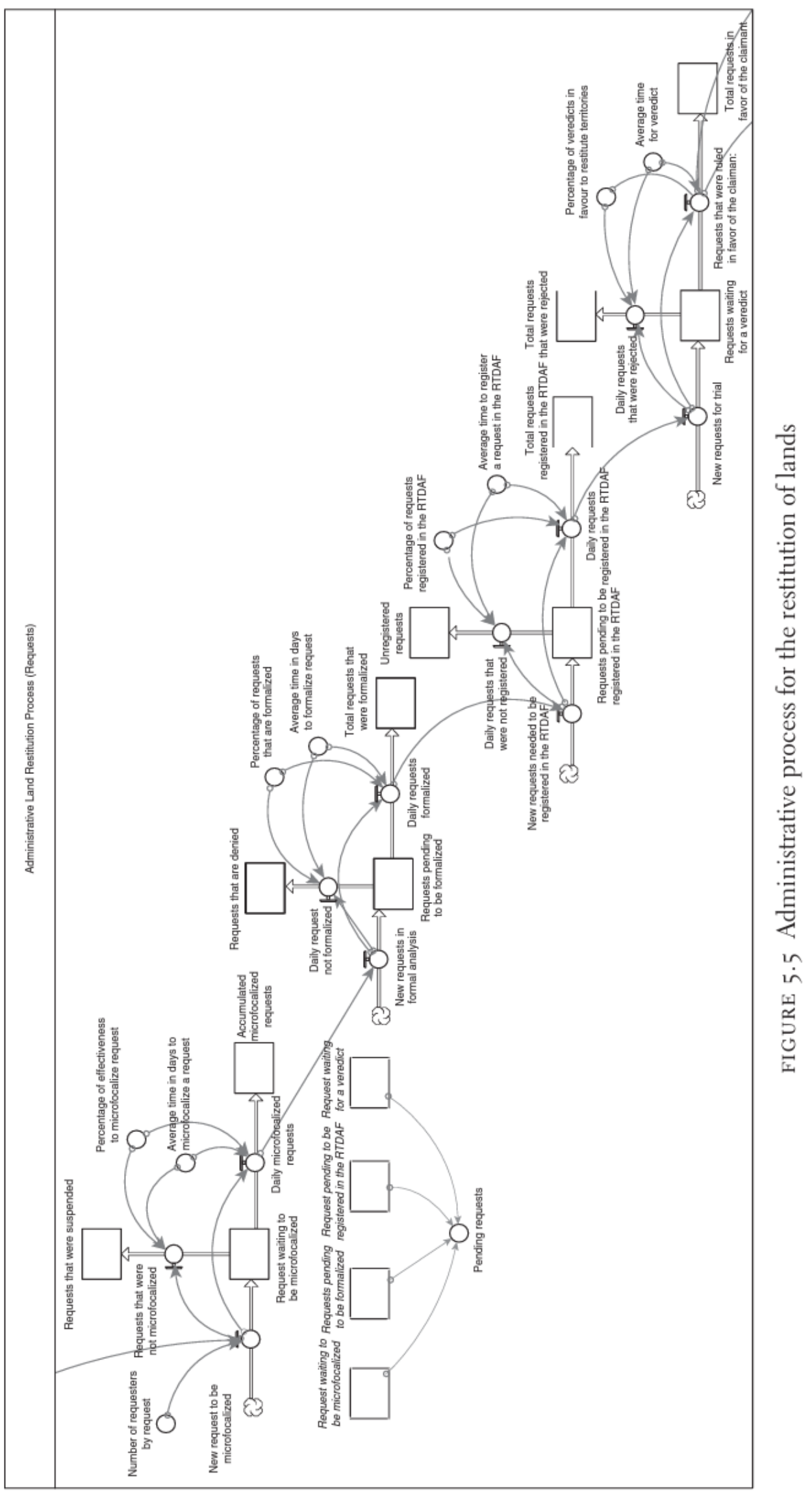




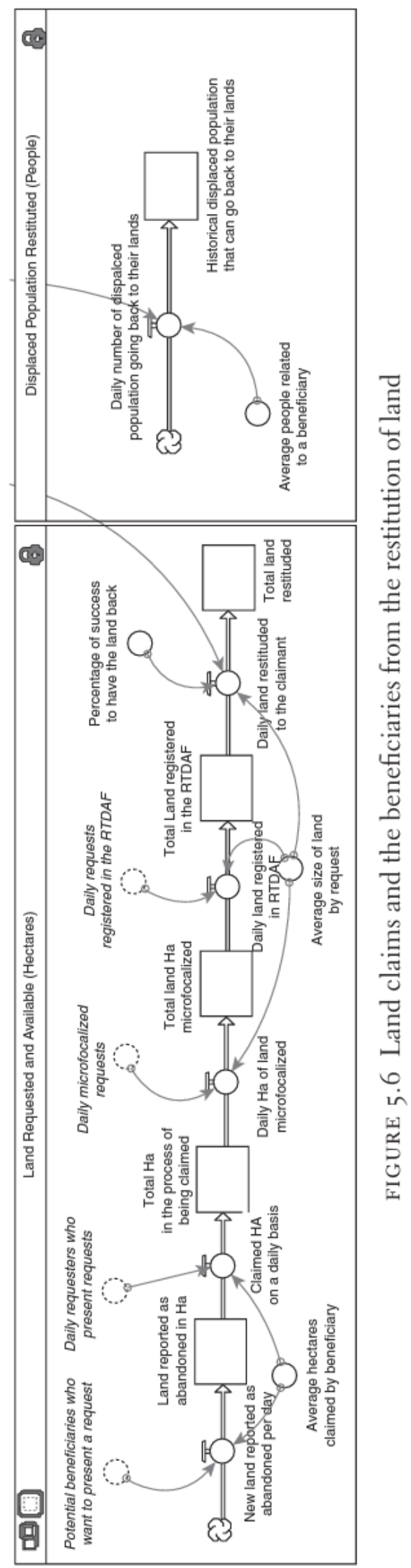


should in every aspect of the process work perfectly. In other words, there are to be no delays, problems concerning institutional capacity, or institutional coordination. The second scenario analyzes the capacity of the law to restitute the victims of forced displacement in relation to the observed times in real practice. This scenario maps the reality of the process in accordance with the observed values and performance of state institutions extracted from the reports provided by the comptroller's office. This is a realist assessment concerning the operation of the law.

\section{FIRST SCENARIO: MAPPING THE EFFICIENCY OF LAW 1448}

Through this scenario, we assess the fulfillment of the goals according to the conditions and deadlines set by Law 1448. The law does not consider elements such as the capacity of the system (the legal system and the land restitution institutions are assumed to have an infinite capacity) with regards to the number of claims to be made by the victims, so we hold this assumption within the model as well. Also, we assume that the performance of state institutions will be in accordance with what has been established in the law, disregarding the number of claims, so that processing times will not be affected by the number of requests. These assumptions are maintained throughout the simulation period. The simulation period comprises a tenyear period, which coincides with the time frame that the law establishes as an objective to achieve its goals. Thus, the first scenario assesses if the law could manage to achieve its objectives within the established deadline.

The main aspects of the law stipulate the following times: ${ }^{7^{1}}$

- The time to receive an application (and process it) shall not exceed five days (Article 86A).

- The time to analyze a request and make a decision if it should be included in the registry from the Unidad Administrativa Especial de Gestión de Restitución de Tierras Despojadas (UAEGRD) is sixty business days, which could be extended by thirty days under specific circumstances (Article 156).

- The evaluation of the documentation and proofs provided by the claimant must be performed in a maximum of twenty days (Article 79, Paragraph 1).

- The probative stage will last at most thirty days (Article 9o).

- The time allowed to restitute the land to the owner is a maximum of five days (Article 100).

7 República de Colombia, "Ley de Victimas y Restitución de Tierras - Ley $144^{8}$ de 2011," Bogotá (Cundinamarca): Diario Oficial 48og6, June 10, 2011. 
This simulation model finds that, over ten years, the total number of people who would get their land back is near 800,000 , which represents a total of 283,000 requests being ruled in favor of the claimants. However, this number would account for less than 15 percent of the victims of forced displacement in the country. In addition, this result is assuming that there are no new victims of forced displacement during the period of the mandate of Law 1448 (2011-21). At the end of the simulation, it would be expected that 7.5 millions hectares would be restituted. This volume would include land that has been reported as abandoned but has not been considered in the official process of reclamation. There is an underlying assumption that there will be a reduction in the displacements caused by the FARC-EP by 31 percent. However, if we consider that between 2001 and 2006 alone, between 2.6 and 6.8 million hectares were appropriated through forced displacement, ${ }^{72}$ the model might not be capable of compensating for the damage caused by various armed actors of the ongoing conflict.

Based on the simulation results, it is also observed that in each stage of the administrative process there is an initial overflow of arriving cases, and it takes some time for the number of applications to stabilize. However, by the end of the legally proscribed period of implementation, the requests waiting for a verdict seem to be increasing, indicating a possible backlog. These results support the argument that the normative obligations defined by the law cannot be achieved in a period of ten years.

\section{SECOND SCENARIO: EFFICIENCY OF THE PROCESS}

This scenario incorporates the information that has been retrieved after the preliminary implementation of Law $144^{8}$ and its assessment by the comptroller's office. ${ }^{73}$ The purpose of this exercise is to compare the ideal type (the prescription of the law) with the practice of the implementation of the law. Similar to the first scenario, we find that the number of people who could go back to their homes and land is considerable, but lower than what is expected in the first scenario. This scenario indicates that there would be capacity to accommodate the needs of around $700, \infty 00$ victims. However, there are implications to consider in practice. As land should be cleared as safe from armed groups, this issue might constitute an unsurpassable hurdle in some cases. Armed actors in Colombia still exert violence as paramilitaries, drug lords, and some left-wing

72 Comisión Colombiana de Juristas, Revertir el destierro forzado: protección y restitución de los territorios usurpados (Bogotá: Estrategias MCP ltda, 2006).

73 Contraloría General de La República, "Informe de seguimiento." 
groups continue to operate in the country. Thus, the existence of violence beyond the FARC-EP will likely hamper the real implementation of these measures. Furthermore, the land restituted at the end of the simulation process lags behind the land reported as abandoned. This result is different from the first scenario, as processes take longer, and requests take more time at the administrative stages than initially envisaged by the law. The law will not be able to reach its target during the established deadline. However, in a longer time period it would be expected that the land restitution' would achieve the same objectives as the first scenario. Finally, when comparing the different stages where the request might be held within the administrative process and the judicial process, again the most critical stage emerges as the judicial trial. As a result, there would be more backlogged requests. Additionally, the requests waiting to be registered in the RTDAF indicate that currently they might be pushing the limits of existing capacity.

Even in the ideal scenario of infinite administrative capacity that can cope with all the requests and claims by the victims of forced displacement (disregarding the capacity of judges and municipal officers), the existing institutions are not able to achieve the goals proposed by the government in Law 1448. To come closer to their realization, a series of corrective measures could be suggested. The first one would be designing policies that reduce the delays in the administrative process without compromising the rigor that is required for the assessment of the claims of victims. Solutions such as those implemented by the URT to try collective claims are another possibility that might prove useful, as this clusters areas, claimants, and processes into groups. However, this scenario still needs to include a clearer depiction of the capacities of the system to deal with the requests, as well as the impact of attended requests on future demand by possible new victims. It could be assumed that if the process is successful for some victims of displacement, more victims will apply for it. If lands are not being restituted, on the other hand, the number of people who apply for the restitution of their lands will decrease; thus, these feedbacks might be affecting the performance of the system as a whole, as well as having significant negative repercussions for peace in the country.

\section{CONCLUSION}

The above assessment of different scenarios allows for a multifaceted interpretation of the feasibility and challenges involved in the restitution of land to victims of forced displacement in Colombia in accordance with the law and its mandates. The data used is excerpted from the reports prepared by the comptroller's office. Based on the findings shared above, it seems evident that the restitution policy will 
not be able to fulfill its mandate within the scope of the mandate of Law 1448. This implies the necessity for government officers to analyze and improve the process. In the aftermath of the implementation of a new transitional justice framework as an outcome of the agreement with the FARC-EP, reflecting on the challenges and difficulties for implementation of Law 1448 can inform future policies for supporting further transition toward peace in Colombia. The model discussed in this article presents a possible venue concerning how to make transitional justice and peace a reality. As such, it presents an alternative, allowing researchers and policymakers to learn about the practical dimensions of the measures to be implemented.

Here, a word of caution is required with regards to this model as well as simulation models in general. A model is just a model. It is not reality, and we cannot collude it with real-life situations. Such models are analytical tools that serve the purpose of learning, reflecting on, and mapping the challenges and operations laid out in laws. Therefore, for a model to inform policy-making with accuracy, a detailed assessment of the policy in question has to be undertaken. Elements such as the capacity of the system to deliver a particular service and the nature of the delays within the process are often not considered adequately. Still, the abuse of computer modeling disconnected from the day-to-day realities they aim to represent must be avoided. This latter use of models implies a nefarious form of armchair empiricism, an approach that would be useless or even detrimental for peace-building.

On the specific issue of land restitution, this process involves both central and decentralized institutions. The interaction of these institutions is vital for understanding the policy initiative. In addition, elements such as the capacity of different decentralized institutions might imply that the delays between different areas of the country might differ. Indeed, it could be the case that in some provinces the capacity of the state allows for successful restitution of the land, yet in those areas where the conflict has been worse, their capacity may be far less. According to the simplified models presented here, the government is not in a position to fulfill the mandate of restituting the rights of the victims of forced displacement fully. In the light of these findings, it is likely that the achievement of the objectives of Law $144^{8}$ will require a careful crafting or in some cases redesigning of the institutional capacities in question.

In Colombia, the clock is ticking. For more than fifty years, Colombia suffered from armed violence between the government and different armed groups, including guerrillas, paramilitary forces, drug lords, and private armies. Although the recently reached agreement between the Colombian government and the FARC-EP allows for redressing the victims of these confrontations, Colombian advocates of transitional justice have been right 
in pointing to the gap between what needs to happen (justice, restitution, memorialization, and/or reparation) and how it needs to happen. In general, the literature on transitional justice is assertive in claiming what needs to be done, but has failed to reflect on how to make transitional justice initiatives a reality, especially taking into account that these initiatives take place in conflict/post-conflict environments. For this, we need to acknowledge that laws do not automatically give rise to efficient public policies.

This chapter has suggested that to transcend the discursive debate of what justice is, and to reflect on tools for facilitating the implementation of policy objectives, any normative or legal claim (about what justice should be in a particular context) must be accompanied with an assessment of possible venues on how to implement efficient measures. The use of managerial practices and conditional assessment of processes via the usage of tools such as simulation models could provide a venue to preemptively consider some of the possible challenges concerning the implementation of initiatives toward building peace. In order to identify bottlenecks, delays, and difficulties so that public policies could be planned more robustly, the case of the victims of forced displacement in Colombia offers us unique insights.

\section{REFERENCES}

Amnesty International. Colombia: The Victims and Land Restitution Law. London: Amnesty International Publications, 2012.

Banco de la Republica de Colombia. "El campo y la ciudad: Colombia, de país rural a país urbano." 1999. www.banrepcultural.org/node/32860

Centro Nacional de memoria Histórica, 2015. "Una Nación Desplazada: Informe nacional del Desplazamiento forzado en Colombia." 2015. www .centrodememoriahistorica.gov.co/descargas/informes2015/nacion-despla zada/una-nacion-desplazada.pdf

Comisión Colombiana de Juristas. Revertir el destierro forzado: protección y restitución de los territorios usurpados. Bogotá: Estrategias MCP ltda., 2006.

Congreso de la Republica de Colombia. "Ley $144^{8}$ de 2011." 2011. www.uni dadvictimas.gov.co/es/ley-1448-de-2011/13653

Contraloría General de La República. II Informe de seguimiento al proceso de restitución de tierras. Bogotá, 2013.

Cour Pénale Internationale. "Report on Preliminary Examination Activities." 2013.

Deng, F.M. "Guiding Principles on Internal Displacement." International Migration Review (1999): 484-93.

Forrester, J.W. "System Dynamices, Systems Thinking, and soft OR.” System Dynamics Review 10, no. 2 (1994): 245-56. 
Garay, L.J. "Tragedia humanitaria del Desplazamiento Forzado en Colombia." Estudios Politicos (2009): 153-77.

Ghaffazedegan, N., J. Lyneis, and G.P. Richardson. "How Small System Dynamics Models Can Help the Public Policy Process." System Dynamics Review 27, no. 1 (2010): 22-44.

Gobierno de Colombia \& FARC-EP. "Acuerdo final para la terminación del conflicto y la construcción de una paz estable y duradera." 2016. www .altocomisionadoparalapaz.gov.co/procesos-y-conversaciones/Document os\%2ocompartidos/24-11-2016NuevoAcuerdoFinal.pdf

Gutiérrez Sanín, F. Un trancón fenomenal. Un analisis de las demoras en el proceso de restitución. Bogotá: Observatorio de restitución y regulación de derechos y de Propiedad Agraria, 2013.

Huertas Díaz, O. "Restitución de tierras, en el marco del conflicto armado en Colombia: Propuesta legislativa de reparación para las víctimas." Verba Juris (2012): 33-45.

Humans Right Watch. "The Risk of Returning Home." Humans Right Watch, 2013.

La Silla Vacía. "Van 27 alertas de la Defensoría y aún nadie detiene el avance de los paras en Chocó." 2017. http://lasillavacia.com/historia/van-27-alertas-dela-defensoria-y-aun-nadie-detiene-el-avance-de-los-paras-en-choco-60570

López, C. "Aprender de nuestra experiencia para que la paz sí le cumpla esta vez a los colombianos." Revista de Ingeniería 44 (2016): 14-19.

Mendoza Pineros, A.M. and J.I. Gonzales Borrero. El desplazamiento forzado en Colombia y la intervención del estado: una mirada desde el goce efectivo de derechos y los factores asociados a su realización. Bogotá: Documentos CEDE, 2010.

Norwegian Refugee Council. "Colombia: Government 'Peace Process' Cements Injustice for IDPs." Internal Displacement Monitoring Centre, 2006.

Norwegian Refugee Council. Colombia El desplazamiento Continua a pesar de las esperanzas de paz. Bogotá: Centro de Monitoreo de Desplazamiento Interno, 2014

Olaya, C. "Model-Based Lawmaking and the Curious Case of the Colombian Criminal Justice System." Kybernetes 9, no. 39 (2010): 1678-1700.

Olaya, C. "Cows, Agency, and the Significance of Operational Thinking." System Dynamics Review 31, no. 4 (2015): 183-219.

Olaya, C., G. Diaz, and A.M. Ramos. "The Power of the Stock: Accumulations in the Clombian Accusatory System Reform," Proceedings of the 26th International Conference of the System Dynamics Society, University of Patras, Athens, 2008.

Palacios, M. Entre la legitimidad y la violencia: Colombia 1875-1994. Bogota: Editorial Norma, 2003.

Pardo, R. Fin Del Paramilitarismo: ¿Es Posible Su Desmonte? Bogotá: Ediciones B., 2007 . 
Procuraduría General de la Nación. "Persiste el incumplimiento en la implementación de la ley y los decretos leyes de víctimas y restitución de tierras." 2017. www.procuraduria.gov.co/portal/incumplimiento-restitucionvictimas.news

Procuraduría General de la Republica de Colombia. Observatorio sobre la gestión de la restitución de Tierras Un proyecto de todos. Bogotá: Procuraduría General de la Nación, 2013.

República de Colombia. "Ley de Victimas y Restitución de Tierras - Ley $144^{8}$ de 2011." Bogotá(Cundinamarca): Diario Oficial 48096. 10 June 2011.

Revista Semana. "Amnistía raja a Colombia en Derechos Humanos." 2017.

Sánchez, N.C. “¿Sera Santos el Salvador de la Resituación de Tierras?” La Silla Vacia, 11 April 2014.

Sato, J.B. and B.J. Stansen. "A System Dynamics Approach to Analyzing Violence, Death and Displacement in Darfur." Conference Proceedings of the 2007 International Conference of the System Dynamics Society, Boston, July 29-August 2, 2007.

Sterman, J.D. "Learning in and about Complex Systems." System Dynamics Review 2, no. 10 (1994): 291-330.

"System Dynamics Modelling: Tools for Learning in a Complex World." California Management Review 43, no. 4 (2001): 8-25.

The New York Times Editorial Board. "The Man Blocking Peace in Colombia." The New York Times. October 14, 2016. www.nytimes.com/20 16/10/14/opinion/the-man-blocking-peace-in-colombia.html?_r=0

Unidad para la Atención y Reparación Integral a las Víctimas. "Víctimas por tipo de hecho victimizante." 2017. http://mi.unidadvictimas.gov.co/RUV

Uprimi-Yepes, R., and N.C. Sanchez. "Los dilemas de la restitución de tierras en Colombia." Estudios Socio Jurídicos (2010): 305-42.

Vargas Reina, J. "Análisis comparativo de los diseños institucionales que regulan la participación de las víctimas en Colombia: antes y después de la Ley 1448 de 2012." Estudios Socio-Jurídicos (2014): 167-207. 